\title{
Borders are galaxies: interpreting contestations over local administrative boundaries in South Sudan Zoe Cormack ${ }^{\mathrm{I}}$
}

\section{INTRODUCTION}

In a recent collection of essays on the history of lines, Tim Ingold argues that anthropologists, and scholars in general, have tended to assume that nonWestern cultures are essentially 'non-linear', in contrast to the linear taxonomies and epistemologies of Western cultures. So, he suggests, alterity is usually assumed to be non-linear. For Ingold, this dichotomy is too rigid. He asks that we move beyond it to look not only for the displacement of non-linear modes, but also to recognize many different kinds of linearity. He writes:

Colonialism...is not the imposition of linearity upon a non-linear world, but the imposition of one kind of line on another. It proceeds first by converting the paths along which life is lived into boundaries in which it is contained, and then by joining up these now enclosed communities, each confined to one spot, into vertically integrated assemblies. Living along is one thing; joining up is quite another (Ingold 2007:2-3).

This article will argue that a more open interpretation of linearity is essential to understanding the making and contestation of administrative boundaries in South Sudan, and so also to understanding the processes of state-building in the region. The colonial state was industrious - and the newly independent state has been even more so - in attempting to lay down lines, which have increasingly become the focus of conflict. Administrative boundaries in many parts of the country are less than a decade old and yet these have become increasingly contested in the years following independence in 2011 (Luedke 2013). This struggle over landscape has unfolded in the often violent and incomplete process of forging the independent state of South Sudan.

My argument, drawing on research in a Dinka speaking part of South Sudan, is that conflicts over local boundaries are rooted in the existence of different border paradigms and in subsequent attempts to resolve, sometimes violently, competing moral claims on the landscape. This situation has arisen because successive states have attempted to accommodate indigenous political geographies into their administrative structures by mapping administrative units onto Dinka territorial sections. The borders of enclosed administrative

\footnotetext{
I Zoe Cormack is currently a research associate in history at the Open University and a research assistant in South Sudanese material culture at the British Institute in Eastern Africa.
} 
units created by the state are nevertheless in tension with a different, Dinka logic of borders as a series of points rather than a line. As this article will explain, this Dinka concept of a border is best understood in terms of a galaxy.

Although these different models of boundary are ultimately rooted in different logics, there has been ongoing interpenetration between 'local' and 'state' geographies since the 1920s. The state is understood here as a loosely coordinated system of institutions, policies, symbols and processes that is collectively given meaning (Sharma and Gupta 2006:27). The administrative units that it has created partly reflect the indigenous geography, but this geography has itself been substantively transformed by the creation of administrative units. This process of interpenetration is comparable to what Beinart et al have argued took place as different systems of knowledge - 'colonial' and 'African' - influenced each other through their mutual encounters (Beinart et al 2009:428). It is a phenomenon that Sharon Hutchinson has described in another part of South Sudan as a 'gradual intermeshing of state and local power networks' since the 1930s (Hutchinson 1996:109).

The eruption of administrative border disputes in recent years might be seen as the culmination of this interpenetration. Far from resisting the imposition of boundaries - as one might expect from the wider literature on pastoralists and states in Eastern Africa - the Dinka pastoralists on whom this papers focuses have instead come to invest in boundaries as a means by which to define and assert political authority and, ultimately, inclusion in the state. But the ways in which they argue for this reveal the persistence of different conceptions and logics of territory and sociality, which continue to undermine the notion of borders as neat, neutral lines of demarcation, and instead assert their value as points of authority and resource ownership. Yet this latter view is also the product of state intervention and indigenous geographies: policies of decentralization and the provision of services and international aid have in many ways followed a similar logic of pathways and points, focusing resources at particular points linked by roads, with the potential for these points to become contested borders.

My empirical focus is local administrative boundaries in a pastoralist region of South Sudan called Gogrial, which is a part of Warrap State. It borders Unity State to the east and sits just south of the contested international border with Sudan. Gogrial is home to the Rek Dinka; with the exception of the comparatively cosmopolitan state capital of Kuajok, it is mono-ethnic. Gogrial is one of the most populous parts of South Sudan; the majority of people live in dispersed rural settlements and practice seasonally nomadic agro-pastoralism. Gogrial was the main field site for Godfrey Lienhardt's classic ethnography of Dinka religion, Divinity and Experience (Lienhardt 1961). His published work and his personal 
archive, recently made available for consultation at the Pitt Rivers Museum in Oxford, make it possible to historicize recent claims and events in Gogrial. This is rarely possible in South Sudan because of the widespread displacements of civil war and because the scant archival records have been damaged by years of conflict and neglect. This archival evidence has been interpreted in light of my own research in Gogrial and Rumbek, over thirteen months, between 2011 and 2012.

\section{PASTORALISTS, BORDERS AND THE STATE}

The topic of boundaries in South Sudan is one aspect of a wider question about the relationship between pastoralist communities and the state. Recent contestation over administrative boundaries in Gogrial shows that pastoralists have not simply been passive victims of state control, they have sought to have an active role in shaping political geography. To understand why this is the case, we need to re-examine the question of pastoralists and borders and the particular nature and history of the state in South Sudan.

Pastoralists are often stereotyped as wandering nomads. Even academic studies of pastoralism in Africa stress the 'unboundedness' of these societies. Gunther Schlee, for example, has argued that pastoralists in northern Kenya did not have a model of, or even a word for, borders delineating surface areas before colonialism (Schlee 2010:6). This South Sudanese case is different. In fact the reason some local borders are the subject of conflict is because administrative borders have been laid over another, radically different model of border.

Underpinning my argument is the fact that concepts of territorial control and power are not universally shared. Crucially, there are ways of imagining territoriality and power that are different from Western, Weberian paradigms of state control which are based on the European experience, where population is dense and the division and control of territory has been a basic mechanism of power (Herbst 2000:36). Several writers have looked at paradigms of territoriality in which power is broadcast from centres in contrast to the Weberian focus on control of defined and bounded territory. In an influential essay, the anthropologist Stanley Tambiah uses the phrase 'the galactic polity' to describe the configuration of traditional South Asian Kingdoms. He shows that there was a model of the polity that stressed the centres of power, rather than its edges. Political units, from lineage-based societies to states, were 'constituted according to an elaborate design of centre and satellites and elaborate biparticians of various kinds,' not the enclosed unit of the modern European model (Tambiah 1977:69-70). In a complementary argument, Jeffrey Herbst argues that in African history, power has typically been concentrated in the 
centre because land was never scarce, and leaders had little incentive to control outlying areas (Herbst 2000:41-45). Models of territorial control focused on centre-points have been described in nineteenth century southern Zimbabwe (Mazarire 2013) and nineteenth century Chad (Reyna 1990).

Studies of pastoralism, meanwhile, have stressed how colonial and post-colonial states have re-shaped and restricted pastoralist landscapes in the East and Horn Africa. Extensive incursions into pastoral land have taken the form of enclosures, the imposition of grazing boundaries, restrictions on movement, the transferal of people and livestock, disease controls, forced sedentarization and the conversion of pasture to commercial and agricultural land (Brockington 2002; Fratkin 1997; Hughes 2006; Waller 2004; Umbadda 2014; Schlee and Shongolo 2011:27-35). Many authors have connected these processes with the deeply unequal relationship between pastoralists and the state (Gamaledin 1993:59), part of a larger process which Abbink calls 'the shrinking cultural and political space' of pastoralist societies in the twentieth century (Abbink 1997).

There can be no doubt that the introduction of fixed administrative boundaries, in areas where human and animal populations are mobile, has been problematic. But in practice boundaries are always hard to enforce. Pastoralists can instrumentalize state borders, and they are often highly entrepreneurial in using them to engage in profitable cross-border trade in livestock and commodities (Catley et al 2013:7). Even in places like Baringo in Kenya, which saw extensive colonial development and environmental projects, pastoralists were able to selectively engage or resist different aspects of state intervention at different times (Anderson 2002:11).

Many of the experiences that characterized the relationship between the state and pastoralists in other parts of eastern Africa are absent in the history of Gogrial. Here there were no colonial settlers or commercial agricultural projects and few colonial boundaries were rigidly enforced. Gogrial was on the geographic and political fringes of the colonial project, even in the context of Southern Sudan. A region in which the colonial state could claim only 'a tenuous authority over the population surrounding their few and far distant administrative posts... but beyond these islands of governance the Imperial aegis was unknown' (Collins 1983:2). By 1947 there were only 42 political officers in the entire territory of Southern Sudan, an area larger than Kenya (Lienhardt 1982:29). Gogrial town itself was only seasonally staffed by an Assistant DC, officials were otherwise based mainly either in Wau or Tonj. ${ }^{1}$ As Willis and Leonardi have argued for the Nuba Mountains and more widely in the South, the power of the colonial state was limited and it did not succeed in creating completely new forms of authority, or the forms of 'decentralised despotism' 
described by Mamdani elsewhere in British colonial Africa (Willis 2003:111; Leonardi 2013:63).

South Sudan is a classic example of an area in which the state lacked, and lacks effective coercive power and employs violence to excerpt control. The sporadic violence of the state, exemplified in the patrols during colonial pacification, wartime counter-insurgency and more recent forceful disarmament campaigns, only highlights its tentative grip. As Herbst, following Arendt, reminds us 'violence and control should not be confused' (Herbst 2000:90-91). Historians of South Sudan have frequently described the extractive, alien and 'nodal' character of the state in the south, which was first based out of trading posts, zara'ib (Ar. enclosure, sing. zariba) then government garrisons, then government towns. More recently, the government army was again confined to military garrisons in the last civil war (Johnson 2011; Leonardi 2013:17-19; Burton 1988).

It is precisely because of the relative weakness of state power here that its practices and institutions have themselves been colonized by other forms of regulation (Das and Poole 2004:8). Whether in spite, or because, of its violent character, the state has been subject to reinterpretation by ordinary people. This article will explain how rural people have inserted state authorities into preexisting terms through which they imagined the geography of Gogrial. Thus it shows how local concepts of geography have not been simply displaced by the state: instead, in complicated ways, the state's geography has been incorporated into existing pastoralist frameworks.

\section{THE CREATION OF ADMINISTRATIVE UNITS IN SOUTH SUDAN}

Gogrial has been divided into administrative units based on the Dinka concept of wust (sing. wut). Wust, which literally means cattle-camps, form the basis of Dinka segmentary political structure. This political organization, similar to that of the Nuer, has been described as 'an expanding series of opposed segments' (Evans-Pritchard 1969:148; Lienhardt 1958:128). As the Seligmans recorded in 1932, there is not a single Dinka 'tribe'. Dinkaphone people are a conglomerate of widely geographically dispersed, autonomous sections and subsections (Seligman and Seligman 1932:135). In Dinka language, the word wut is used to describe segments of various sizes. In Lienhardt's English terminology, the largest of these sections are 'tribal groups.' In Gogrial the 'tribal group' Rek is divided into the 'tribes' / wust of Apuk, Kuac, Aguok, Awan Chan and Awan Mou. These are themselves composed of 'subtribes'/wust. Apuk has nine Kuac has six and Aguok has twelve, which are further are divided into smaller 'sections' /wust (Lienhardt 1958:102-104). 
As implied by the metaphor of the cattle-camp, the wut is more than a simple territorial division. It expresses the holistic notion of a grazing community, rooted explicitly in the intimate relationships between people and cattle. These are corporate social and political entities bound together by bonds of decent, kinship and reciprocity. Wust embody relationships of affinity that in the twenty first century, following years of war and displacement, may extend as far away as Kampala or Philadelphia.

Wust are entwined territorial and social communities par excellence. Yet despite the multifaceted forms of connectivity embedded in wust, they have been coopted as territorial units into local government structures. Two distinct phases can be discerned: one initiated by the colonial state (1923-c.1953) and the other by the SPLM/A military and GoSS administration (1994-present), when significantly more new administrative divisions were created, also based on wust.

Colonial administrators identified several 'units' as the potential bases of Native Administration in Dinka areas. These were what they understood as territorial communities, which they called kraals or used the Dinka word wut; clans (lineage based descent groups, Dinka dhieth); and gol (extended family groups). The administrative question was which of these identities was the most effective basis for rule. In the 1930s administrators saw an evolutionary progression away from what they perceived as more arcane lineage-based identity and towards 'modern' territorial based identity. Territoriality, they felt, should be encouraged, as part of the 'natural development of Dinka life'. ${ }^{2}$ By the 1940s, the government was convinced that it had to use territorial groups (wust) with their own 'government chiefs' as the basis for native administration. A meeting of Dinka District Commissioners in 1938 recorded a clear statement of this approach:

Our policy should be to foster this tendency towards territorial tribal unity as being the only means by which a Native Administration can govern the hopeless mixture of clans and family groups that constitute the Dinka tribal structure. ${ }^{3}$

Colonial officials wanted to imagine Dinka governance as neatly territorial. However, it proved difficult for the administration to use territory exclusively because of the constant movement of people and cattle and the hopeless mixture' of other forms of relationship.

The colonial administrative system was based on large territorial chiefdoms centred on different wust. The primary concern was that these chiefs oversaw tax collection and road work. ${ }^{4}$ Gogrial was divided into administrative chiefdoms 
based on the wust of Kuac, Aguok, Apuk and Awan (two chiefships). The Tuic Dinka, in the north of Gogrial were split into four administrative wust (see map 2). The three most important colonial chiefs in the area referred to at this time were Amet Kuol in Kuac, Kuanyin Agoth in Aguok, and Giir Thiik in Apuk. These were men who were able, or are remembered as having been able, to negotiate effectively with the government. ${ }^{5}$ Several of these chiefs were also key informants for Lienhardt (Lienhardt 1961:vi).

Wust existed in Gogrial before the colonial state (Lienhardt 1958:103). Nevertheless, the state at this time attempted to create larger and more stable territorial units across Southern Sudan. This was particularly clear in other pastoralist parts of South Sudan, such as Jonglei, where the presence of Dinka and Nuer groups together in the same district resulted in early policies to enforce boundaries and strengthen the territorial units, partly as a security measure by encouraging separate, ethnically defined grazing areas (Howell, Lock, and Cobb 1988:243-244). Attempts to separate ethnic groups that were not clearly defined created more problems and these borders often intensified security issues, so that some officials abandoned these policies (Johnson 1982:195,197).

However, there was not such strict enforcement of territorial units and boundaries in Gogrial. Gogrial was perceived as ethnically homogeneous (a Dinka district) and the government saw no need to enforce territorial divisions for security reasons. In comparison to districts like Jonglei or even neighbouring Aweil, the colonial state took a markedly less interventionist approach to demarcating boundaries in Gogrial (Johnson 1982; Santschi 2013:89). Relative lack of detailed understanding seems to have characterized the colonial administration's position on its own administrative boundaries. For example, greater enforcement of boundaries between Gogrial and Aweil District (now Northern Bahr-el-Ghazal State) were discussed, but never enforced. ${ }^{6}$ Although officials acknowledged that they theoretically needed to define the boundary in order to collect taxes, they concluded they lacked adequate local knowledge to know where the boundary really was, so did not attempt to enforce it. ${ }^{7}$ Other exchanges visible in the archival record highlight how partial official understandings of territorial divisions were in this period. One District Commissioner told Godfrey Lienhardt, incorrectly, that the only border within the Apuk section was simply the River Jur. ${ }^{8}$ Yet we know from Lienhardt's own research that, even at the time, this was an oversimplification and informants had described other sub-sectional units (wust) within Apuk to him. ${ }^{9}$

After Sudan's independence there was a series of reforms to local government, but due to poor security and budgetary shortages, these were never properly implemented in the South (Norris 1983:216). It was not until the second civil 
war (1983-2005) and the SPLM/A administration that local government in the South substantially changed (Johnson 1998:67). The SPLM/A sought to construct 'liberated zones' which it administered militarily (and often highly predatorily). (Reno 2011:29-30) In some areas this was effective from as early as 1985. If the colonial state laid the foundations for territorial administration in Gogrial, then the SPLM/A's administration grew out of this system both structurally and ideologically. The SPLM/A used wust and chiefs as the basis for local government. The remnant colonial administrative areas were divided and made into new administrative areas called 'Counties', 'Payams' and 'Bomas' (Rolandsen 2005:69). This military administration used the old chieftaincy structure integrated into a military hierarchy. It was, like the colonial state, extractive; local populations were expected to provide the military with recruits, cattle and other supplies (Johnson 1998:67).

In 1994, in the context of an increasingly factionalized rebellion, the SPLM/A held its first National Convention at Chukudum and attempted to reform and liberalize its structures (Rolandsen 2005:64). Among other things, this National Convention formally established a programme of decentralization in liberated areas' (Leonardi 2013:186-187). A new system of civilian administration, which was theoretically to be separate from the military, was implemented (Rolandsen 2005:158-159). One result of these structural changes was the establishment of even more Bomas, Payams and Counties (Harragin and Chol 1998:42).

Since 2005, administrative divisions have even further proliferated. The GoSS administration also attempted to map its new administrative geography onto the territorial geography of wust. Instead of only reflecting the larger sections, as the colonial state had done, smaller wust were now being used as the basis for payams and bomas (Leonardi 2013:185). Post-CPA local administration in Gogrial is the most comprehensive attempt to transform Dinka segmentary political structure into administrative order. In the last decade, the number of administrative units in Gogrial has slightly more than doubled. In 2005 Gogrial County was split into two counties: Gogrial East (with six payams made up of thirteen bomas) and Gogrial West (with nine payams made up of twenty-nine bomas). ${ }^{10}$ The 2009 Local Government Act stipulated that the boundaries of these units should be demarcated (GOSS 2009a). However, as I will discuss below, much of this demarcation has yet to take place.

Across the country, this process has been accompanied by an increase in tension at borders (Rolandsen 2009:24; Schomerus and Allen 2010:40-43). Focus on administrative units was a central part of local debates around the 2008 census (Santschi 2008:637-638) and in 2011 one government minister even called for a moratorium on the creation of counties because of its 'destabilizing impact on national integration' (Nyaba 2011:30). 
Part of the reason why administrative units have become increasingly controversial is the perceived benefits attached to decentralization. During the civil war (1983-2005) local populations often led calls for increased administrative divisions as these were a way to access foreign NGOs that were providing services and relief (Rolandsen 2005:161; Leonardi 2013:183). Observers of decentralization in South Sudan since 2005 have argued that allocation of government resources through salaries and patronage has been structured around the decentralized administrative system, making this a key way that local people can make claims on the state (Thomas 2015:138-139). Further, conflation of ethnic identities with administrative boundaries has made demarcation of boundaries a primary trigger for conflict as government resources rather than water and pasture have become sought after spoils to fight for (Schomerus and Allen 2010:40).

Gogrial is a mono-ethnic area, although the new state has attempted to co-opt local divisions of wust into administrative structures. The seamless cooption of wust (or indeed ethnicity) into administrative order has always proved impossible because of the inherent contradictions in converting wust's kin and reciprocal qualities into exclusively territorial units. Yet, decentralization has enhanced the political significance of territorial identity. This is exemplified by the widespread call for new administrative units across South Sudan. In Gogrial as more widely, these appeals were often connected to people seeking to access the resources of the state, or expressing frustration over perceived inequalities in the distribution of government resources. It is revealing that a central part of the Government's 2014 peace deal with David YauYau's rebellion in Pibor was the creation of a new administrative area (Todisco 2015). In the years following Independence, such concerns were also more quotidian, for example in 2012, a chief from Alek West Payam in Gogrial West Country addressed government officials at a community meeting with this following statement:

I feel neglected because we are left out of everything: for example, we are denied our position in the government, also all the development facilities like roads, schools and so on. Sometimes I ask myself, but I cannot get the answer, are we not part of the government?

He went on, turning to the senior officials, 'the big bulls', of the government who were present:

All you need to know is the big bulls that take the lead in the cattle-camp (miordit mac yok nhiim) will come back and the calves that have been neglected will take the lead. 11 
This sentiment, expressed by projecting the image of the cattle-camp (wut) on to the administration, is a striking example from one of anthropology's own classic 'stateless' societies (Middleton and Tait 1970:2), of the desire for inclusion in state structures. It reflects the SPLM government's political practice in which creation and control of administrative units is the primary way of doing local politics and redistributing wealth (Thomas 2015:138).

This particular South Sudanese configuration of ethnic patronage politics is key in explaining tensions around administrative units, as community leaders and a political class have sought to position themselves in relation to opportunities associated with the nascent state. Yet conflicts, like the one I will describe at Mayar in late 2011, were not solely over resources. If we are to understand the sometimes-violent local responses to SPLM led processes of decentralization, we must acknowledge the complex layers of meaning at these border areas. What was at stake at this border: who had authority and what kind of authority did they have? This is a question that can be addressed by asking what a border really is.

\section{BORDERS ARE GALAXIES}

Neither the colonial state nor the newly independent state of South Sudan met an empty space when they attempted to impose administrative division in Gogrial. My argument is that borders already existed but they were conceived not as lines, but as points. It is the particular history of interpenetration between these different paradigms of the border that is essential to understanding both why local border conflicts arise in this region and how state and pastoralist geographies more widely can be mutually constitutive.

The Dinka word for border or boundary is akeu. Akeu is also the word for the Milky Way galaxy because it is that which divides the night sky. This analogy between a border and a galaxy encapsulates the idea of a pointillist border. Galaxies are not lines; they are millions of stars clustered together, stars that appear as points in the night sky. Like the stars that define the shape of the Milky Way, borders are formed from points, rather than lines.

In Gogrial, borders are always referred to as 'points'. Villages, cattle-camps or landmarks represent the border between territorial sections and subgroups of people, which often coincide with administrative units (bomas, payams and counties). For example, if you asked someone, in 2012, 'where is the border between Gogrial East and Gogrial West', the answer would be, 'Pan Acier'. This small village is also referred to as the border between the wust Apuk and Aguok. On the sandy road between Luonyaker and Yiik Adoor in Gogrial East there is a 
village called Marol, which was always pointed out to me as the border between Pathuon East and Pathuon West Payam and, simultaneously, as the border between Adoor and Amuk wust.

Expressions of the border as a point can be found everywhere, from everyday remarks, to songs, to disputes. In a well-known song about the borders of the wut Apuk, the borders are listed as a series of named points

\author{
Akal lek wek akeu war le tok Mading Aguok ku Muonyjiang \\ Mayen Kuac, akeu da ya \\ Nyinaksu to thiok a Wau, akeu da ya \\ Ku Biok, Mayar Ayer, akeu da ya \\ Ku Mer Ayii Manyay, akeu da ya \\ Mabior Atok buk akeu da ya \\ Ku Adhildhil, Adhildhil Mayar Dey Kuol, akeu da ya \\ Ku Ney to thiok ke Nuer, ee akeu da ya \\ Ayen Tuic akeu da ya
}

I am telling you, the historic border is Mading Aguok and Muonyjiang.

Mayen in Kuac is also our border

Nyinakou close to Wau is also our border

And Biok of Mayer Ayer is also our border

And Mer of Ayii Manyang is also our border

Mabior Atok is also our border

And Adhildhil of Mayar Deng Kuol is also our border

And Ngeng close to Nuer is also our border

Ayen in Tuic is also our border. ${ }^{12}$

References to the border in songs sung by young men also highlighted the potential danger of the border as a point of interaction, particularly grazing borders, where different cattle herding communities meet in the dry season and compete for water and pasture. There is undeniable danger at the border; it is the kind of place where your cows might be stolen and shots might be fired. The border is significant precisely because it is a meeting point. It is precisely these points of interaction that embody the border; there is no sense of a dividing line.

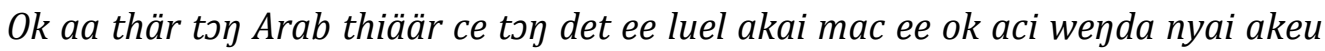
yic.

We have fought ten times with Arabs; we have had our cow taken at the border.

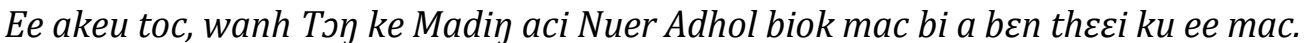
At the grazing border, at the ford of Tong and Mading, the Nuer came and shot at us with guns, they came in the evening. ${ }^{13}$

Earlier research has also recorded this model of the border as a point. In his 1970s ethnography of an Agar Dinka community in Rumbek East, John Ryle gives 
a striking example of where the border is materialized in a discrete nodal point, in this case a body of water. He describes a tour he was given of the community's territory: 'we found the northern limits some 20 miles away at a pool called Akeu, a Dinka word meaning 'border', where the river spreads into papyrus swamp' (Ryle and Errington 1982:32).

The idea of the border as a series of points speaks to the wider scholarship on pastoralist nodal geography. Point-centered notions of land and geography are well documented in many pastoralist societies - as cattle-keepers move between key resources like water and grazing points. Turner describes how Fulani land systems consist of 'an unbounded, point-centred spatial pattern...with rangeland access governed by grazing radii around tenured points... rather than bounded rangeland territories' (Turner 1999:108). This is very different from the enclosed units that the administrative logic of the state implies.

The next part of this article will explain the significance of these different border paradigms: the administrative line and the Dinka points. Places that were the borders between wust are now also administrative borders. These are distinct ways of imagining territory and mapping claims onto the landscape. As a result, borders have become salient - and frequently contested - sites for the performance of identity and authority.

\section{DISPUTE AT MANAR}

Mayar is a settlement on the main road between Kuajok and Gogrial town, the largest of several villages on this stretch of road. It is distinguishable by a few small shops, a few concrete buildings and a school that was not functioning for most of my fieldwork because it was being used as an army barracks. Mayar is known as 'the border' between two administrative units - Monyjooc boma (in Kuac North Payam) and Ajak boma (in Gogrial Payam). Manar is also the border between two wust of Rek Dinka - the Monyjooc section of the Kuac sub-tribe and the Ajak section of Aguok sub-tribe. So it is said to have existed as a border before it was an administrative border. Ownership of 'the border' (Manar) is now claimed by leaders of both the Ajak and Monyjooc wust.

On 29 and 30 December 2011 a dispute erupted in which six people were killed, including a child, and many others temporarily displaced (Sudan Tribune 2012). ${ }^{14}$ The dispute was ostensibly about which community 'owned' Mayar. The trigger was a letter sent on 28 December by the deputy executive chief of Ajak boma, in which he refused to allow a Monyjooc community meeting to take place at Mayar, on the grounds that Mayar 'belonged to Ajak.' But the meeting went ahead with several high-ranking government officials from Kuac in attendance. 
A letter was sent from the Ajak community chairperson to the Kuac community stating

We the community of Ajak hereby inform you that this meeting is refused and we are saying this meeting should stop now and it should not continue anymore. If you know this area belongs to Ajak and Aguok community since time [sic]. We will try to solve this problem peacefully if you have a say about Manar Ajak. ${ }^{15}$

The community meeting, to which this letter alluded, was the latest in a series of encounters during which disputes were aired, that centered on this border village. Most of these disputes concerned, in various ways, symbolic claims of ownership. The naming of the village was a particular point of contention. The 'Ajak community' was angry that the 'Monyjooc community' appeared to be trying to change the name of the village. The village, they claimed, had 'always' been commonly known as Mayar-Ajak (Mayar of Ajak, it asserts ownership). But a few months earlier (at a different Monyjooc community meeting) a new sign had been erected in the village, attempting to rename it 'Manar-Monyjooc'. Although some Ajak representatives were at the meeting, none of them could read, so they had not realised the significance of the sign.

Ajak grievances were also related to struggles over recognition of community ownership at the 'national' level and intersected with citizenship claims and desires to be recognized in the new state of South Sudan. It happens that Mayar is on the road to Akon, the home village of South Sudan's President, Salva Kiir. Since 2005 Kiir had driven through Mayar about once a year. The Ajak community had alleged that, when the Presidential convoy had driven through Mayar in 2010, the flag of Monyjooc boma had be raised at Mayar and the Monyjooc community had prevented them from jumping over a bull which had been slaughtered in honour of the President. This had prevented a display of Ajak community and national pride.

On the other side, the Monyjooc complaints were that Ajak had tried to prevent them from holding community meetings at Manar - which they felt entitled to do. They claimed that at the last community meeting, people from Ajak community had not only written a letter trying to prevent the meeting, they had removed the Monyjooc flag and stolen the goats that had been slaughtered for guests. They made allegations of various other unlawful activities, not all directly connected to the border, but which were articulated as 'community against community' crimes. For example they complained that a Monyjooc man, who had eloped with a girl from Ajak, had been killed by members of her family and no one had yet been brought to justice, and that a man from another Aguok wut had for the past two seasons let his cattle graze on cultivated land in the Monyjooc area, damaging the crops. 
Ten days after the violence erupted, a peace meeting was held, attended by the Commissioner of Gogrial West and the Deputy Governor of Warrap State. The two communities were formally reconciled, they agreed to be disarmed and a purification ceremony was performed by spiritual leaders (bäny bith) from each side. ${ }^{16}$ There were many layers to the Mayar dispute, but the central bone of contention was the question of who had authority at this border village. As the author of the letter to the Kuac community put it: to whom did Mayar belong? This question of authority was rooted in competing models of what the border actually was. Although there was a formal 'resolution' to this conflict and purification rituals were performed, the issue of the ownership of Manar was not fully resolved. The state authorities were not able to say to whom Mayar belonged. The resolution committee had to recommend that the problem of Manar and who owns it is purely an administrative issue which needs to be solved peacefully with clear studies and research', indicating that they did not know what to do about the situation. ${ }^{17}$ In the end, Warrap State and Gogrial West County authorities agreed to 'supervise, control and monitor' the resolutions made at the peace meeting. This was articulated in strikingly synchronistic terms: to 'ensure that whoever violates [the peace agreement] shall bear the consequences and be punished severely by Nhialic (God or Divinity) and [the] living souls of ancestors and [the] full force of the law'.18

\section{INTERPENETRATIONS}

There is evidence that various governments thought of the geography of Gogrial in terms of bounded units - discrete areas, containing communities of people who could be taxed and administered. The colonial government and the GoSS have attempted to align these units with the territories of wust. But, as we can see, recent administrative divisions have not simply involved imposing a border where there was no sense of a border before. Rather, they have meant that two different paradigms of a border must be negotiated: the pastoralist concept of borders as points set alongside the state's definition of enclosed lines of administrative units. One of the critical differences between these is that the state lines are supposed to be neutral - a line does not connote ownership whereas, the point-centred border does imply that the border point 'belongs' to somebody. This issue was at the centre of the Mayar conflict.

However, suggesting that there are different models of boundary existing in tension should not imply that these are isolated from one another and have not, in complicated ways, shaped and responded to each other. Neither should it imply that attempts to demarcate and map out lines 'on the ground' have been 
straightforward. Conversely, it is evident that although the state might imagine enclosed units and lines, these have not been easily imposed. Many of these lines have never actually been mapped. It is because of this functional dissonance that the most interpenetration over the construction of borders occurs. The state might think in terms of lines, but how much do these lines actually become a reality? I will suggest instead that borders encapsulate composite meanings, continually negotiated by 'the state' and local people - which are becoming increasingly contested

It is precisely their partial imposition - the parallels and discontinuities between different models of the border that make the struggles over entitlements particularly complex. These competing logics of what the boundary is can have violent results as communities struggle to assert legitimate authority in an ambiguous landscape. It is this ambiguity that led to the contested administrative boundary in Manar.

The GoSS's use of wust has been partly an attempt to gain local legitimacy and partly a reflection of local demands to have different wust represented within the administration. The interpenetration between 'African' and 'colonial' ideas and authority has been well discussed in African history. In a follow up to his influential essay on colonial rule, Ranger argues that 'traditional' operatives of rule used by the state were not simply 'invented', but were 'imagined' in an iterative process between administrators and local populations (Ranger 1993). Building on this, Thomas Spear points out that colonial territorial chieftainship had to be perceived as legitimate in order for it to be accepted (Spear 2003:4).

Considering the maps made of administrative units helps to show that governments have conceptualized administrative lines across Gogrial, but that the practical consequences have been more complex. Two administrative maps of Gogrial, one published in Sudan Notes and Records in 1927, the other drawn by Lienhardt from government files (c.1947) reveal something about the nature of the colonial engagement with and use of wust. The first map (Figure 1), included in an article by ADC Titherington, is among the first administrative maps of Gogrial to be drawn (Titherington 1927:205). It shows the names of the main wust that the government used in administration (erroneously labeled as 'clans'). The dotted lines do not indicate boundaries between wust, but show the major roads used by the government. The dashed line (running just north of Kuajok mission) shows the estimated position of the end of the ironstone plateau. The River Jur and Lol (tributaries of the Bahr el Ghazal) are both marked. 


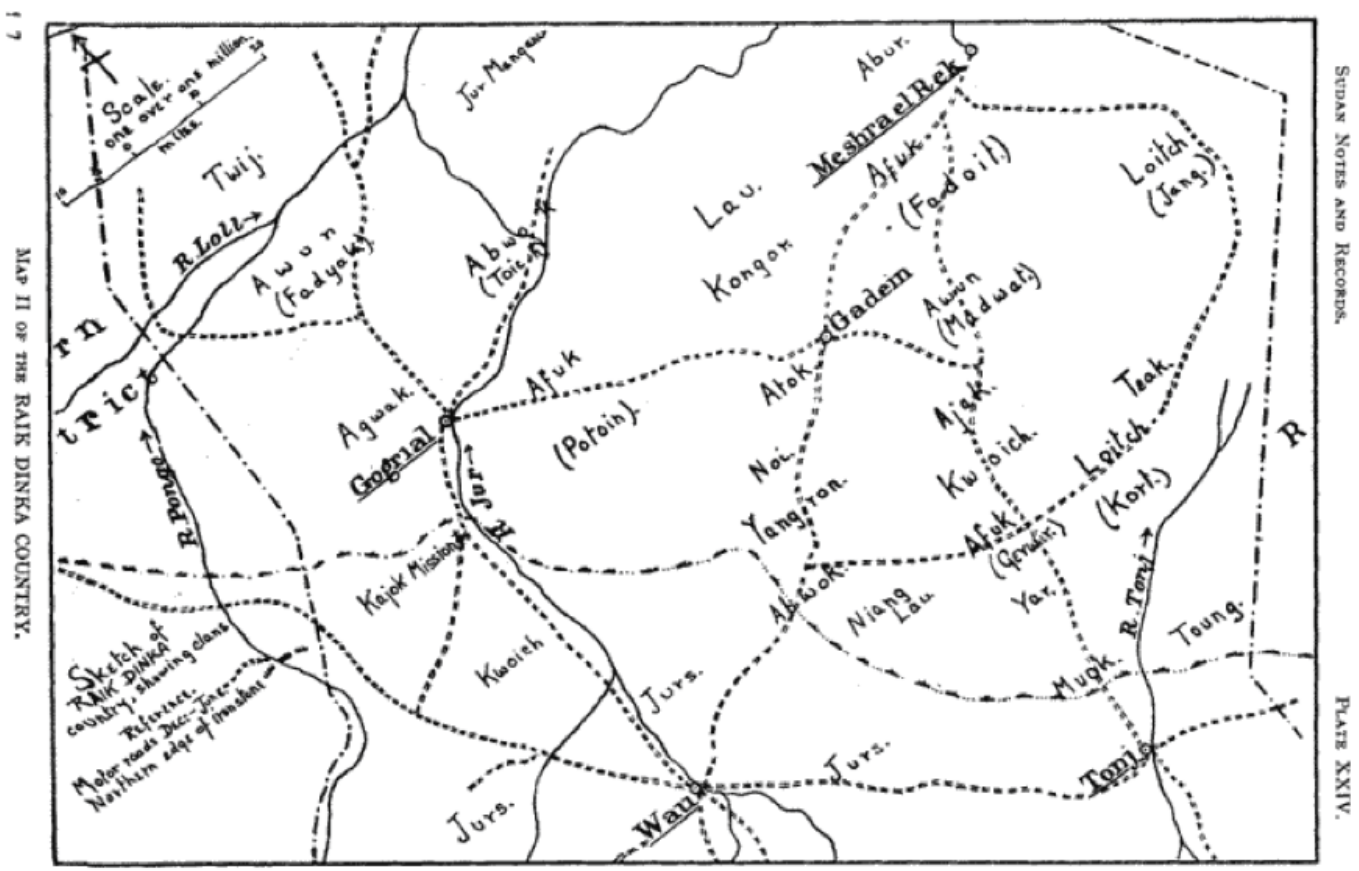

Figure 1 Assistant District Commissioner Titherington's map of the Rek Dinka. Published in Sudan Notes and Records, 1927.19

Compare this with the second map (Figure 2), drawn in a notebook by Godfrey Lienhardt from contemporary local administrative files, which shows the areas of these wust in the late 1940s. ${ }^{20}$ The numbers indicate the number of taxpayers. These maps illustrate the process of administrative enclosure that occurred in the first 25 years of colonial administration in Gogrial. They show a shift from an initial awareness of territorial wust, to the demarcation of these units and the extraction of resources, clearly visible in the bounded units and tally of taxpayers in the second. 


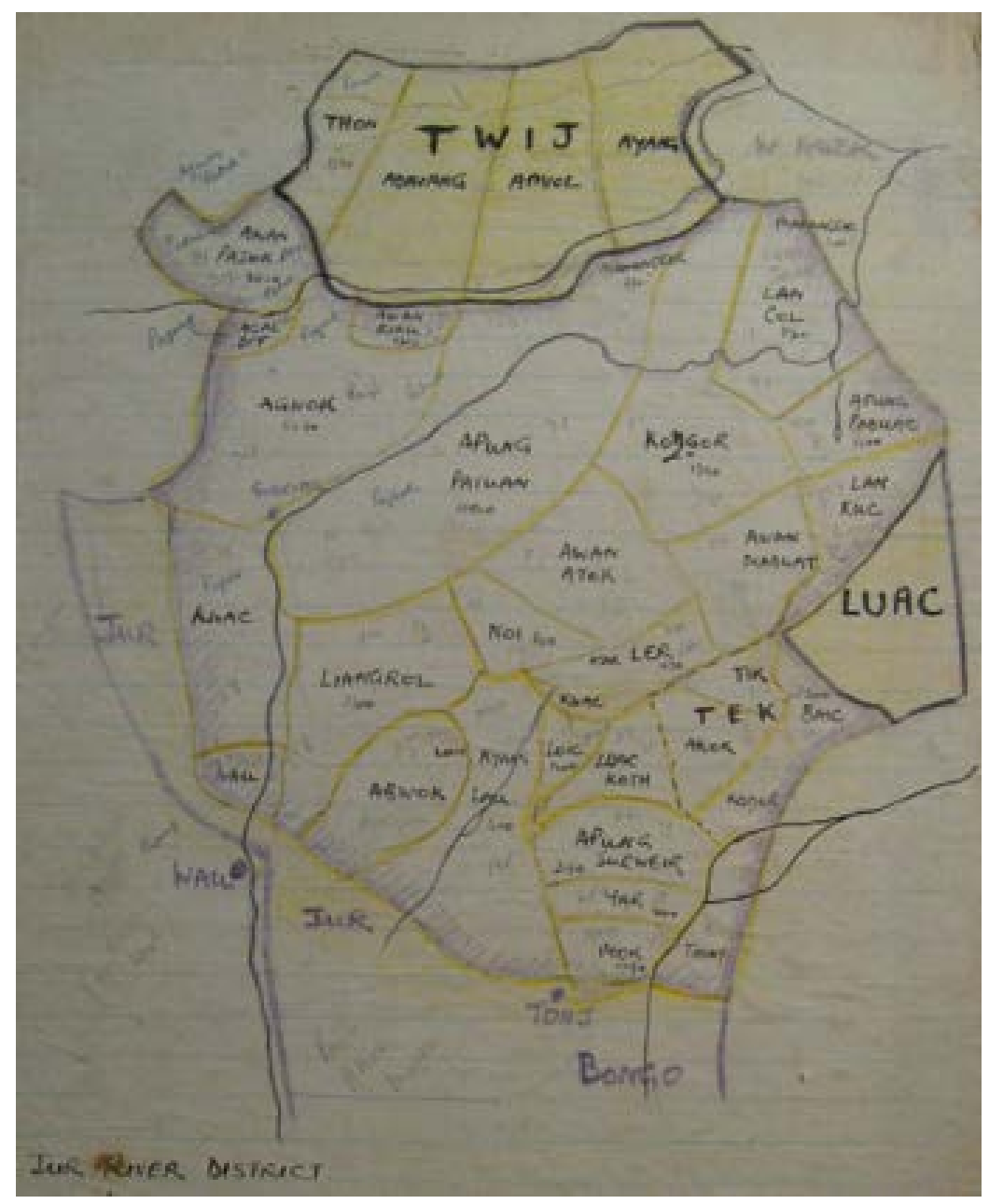

Figure 2 Godfrey Lienhardt's sketch map of Jur River District. Copyright Pitt Rivers Museum, University of Oxford. Godfrey Lienhardt Papers Box 1, Item 4.

This second map (Figure 2) is a hybrid. It is not only a government map; it is simultaneously part of the construction of Lienhardt's anthropological knowledge about wust. Lienhardt's field notes show that he based much of his understanding on conversations with Chief Giir Thiik (and other chiefs). On occasion he specifically asked Giir to explain to him the wust 'before the government came' and Giir Thiik drew diagrams of this for him. ${ }^{21}$

Lienhardt believed that the state had had relatively little impact on peoples' lives. Reflecting on his research in Gogrial he wrote:

It is because so much of the Government's place in the lives of the Dinka and others went no deeper...because traditional forms of political control were so strong just below the surface of modern government and so ready to reassert themselves that social anthropologists have been able to write a great deal about these people without dwelling on their colonial rulers (Lienhardt 1982:34). 
Much of what I am arguing broadly supports this idea that government administration did not displace other forms of authority. But this statement does need to be unpicked. Much of Lienhardt's own understandings came from men like Giir Thiik: men whose authority was, in large part, derived from the government's system of administration. When Giir Thiik emphasized the precolonial character of the contemporary wust, he had a vested interest in representing the system as the way things had always been. In subsequent interviews with Francis Deng in 1972, Giir Thiik continued to stress the precolonial nature of chiefly and territorial authority. He told Francis Deng,

All this talk - you son of Deng, there were great men who were keeping this country...they would run their country...they would meet and talk about such things as how people should relate to each other at borders...chieftainship is an ancient thing; it is not a thing of today. A country is lived in because of a chief (Deng 1978:114).

This does not mean that there was no historical reality to Giir's claims, but there were also reasons that such claims were hardening at this time in response to the potential power of the government.

No official maps of the current smallest administrative units (bomas and payams) of Gogrial have been made available. In 2009, the cartography department of Southern Sudan Centre for Census, Statistics and Evaluation issued a map of the counties of South[ern] Sudan. (GOSS 2009b) In 2008, the UN had produced a slightly more detailed map showing the payams - but with a warning that the payams were in the process of being redefined and that the data it had used 'could not [be] considered [...] correct' (UNOCHA 2008).

During my research I tried to find a map of bomas and payams in Gogrial. I asked at the Ministry of Local Government in Kuajok and at payam administrator's office in Luonyaker in Gogrial East. Such a map did not appear to exist. In fact, the local administrators in Gogrial were using an understanding of the borders of administrative units which was based not on maps (as these had not been drawn) but on a Dinka concept of the borders as points. The way these borders function is as compounds - borrowing elements from both the administrative line and the Dinka point.

One of the most striking things about Titherington's early map of Gogrial is just how much it resembles this construction of the landscape as a constellation of points and pathways. On it, unbounded communities are represented as points, which are intersected by roads. Of course, it was through conversations with local intermediaries, as well as through their own research that this map was drawn. Maps are technologies of rule, but this map could also be seen as an early 
example of a more interpenetrated kind of geography (Bender 1999). The state's control in South Sudan was 'arterial' in the sense that outside of its nodal centres it focused on major river and road routes. These roads patterned the landscape with new and different pathways. In an interview in a small village of Angui (near to Kuajok) in 2011, an elderly man called Bol Cuor described the coming of the British administration as the time when roads started to be made by hands (cath ciïn), not by feet (cath cok). ${ }^{22}$ He meant that before the government arrived, people and settlements were connected through paths made by habitual walking. When the government came, roads were instead purpose built, through conscripted manual labour. Roads, perhaps even more so than towns, are closely associated with state coercion (Thomas 2010:85-101; Tuttle 2013:81). ${ }^{23}$

\section{POINTS OF CONTENTION}

Interpenetrations and tensions between the government's attempt to impose borders as neutral lines and Dinka concepts of borders as points are evident in the colonial period. One revealing case was associated with a long running border dispute between the Luac Dinka under the chiefship of Mayen Tuc in Tonj district and the Agar Pakkam Dinka under Wol Athian of Rumbek district. This is now the border between Lakes and Warrap states and is still contested (Sudan Tribune 2013). Although this took place in the border of Tonj District rather than Gogrial itself, the records of this dispute are particularly good and help to explain my argument. In 1938, an incident of fighting followed the government's implementation of a grazing border two years previously in 1936 running through a river or lake (it is referred to as both) called Teep. ${ }^{24}$ This well watered grazing and fishing area of toc had, at this time, been contested for over sixty years. The 1938 violence spurred a re-investigation by the colonial government into the border.

Both sides (Luac and Pakkam) claimed ownership of the grazing area and a mediation was held. The Luac claimed that sixty years previously, a wooden cattle peg had been driven into the ground at a cattle camp called Tocdor, within the disputed area, and that this peg constituted the border. The Pakkam did not accept the claim, holding instead that the peg marked the spot where a bull had been slaughtered during peace-making ceremonies, and hence it signified peace between the two communities. ${ }^{25}$ To help resolve the dispute, chiefs from other parts of Rumbek had been brought to hear the discussion. They sided with Pakkam argument, which held that the peg was not the border. Foreshadowing some of the debates at Mayar, the chiefs argued that the real issue was not demarcation of the border, but who 'owned' it. They agreed that Lake Teep was the border as the 1936 agreement suggested. But the border that the government had demarcated had not worked, they explained, because it failed to 
say to which community it belonged. The true answer to the question of ownership was difficult to resolve, they believed, because both the Luac and the Pakkam had a historical claim on the basis that both of their ancestors had been buried there. ${ }^{26}$

The root of this conflict was about claiming legitimate authority at the border. The border line which the government tried to enforce was problematic partly because it was neutral and did not resolve local claims on the border point. This is remarkably similar to the dispute at Mayar. It is also important to note that the government attempted to accommodate 'historic' and locally meaningful border claims as it proceeded to try and map and delineate its own border. The DCs had initiated consultations and 'trekked' in the areas before mapping the border along the Teep. ${ }^{27}$ They were prepared to engage with the Dinka galactic border; if Pakkam had agreed, the DCs would have accepted the Luac claim that a peg was indeed the border. ${ }^{28}$

Border disputes in toc grazing lands are relatively frequent because of the importance of the resources (water, fish, pasture) available there (Makec 1988:181). One of the notable points about Mayar is that it is not a grazing boundary; this was a novel kind of boundary dispute, related not to competition over shared natural resources but to obtaining a place in a new administration. Questions about citizenship and securing a legitimate place in the new independent state of South Sudan were central to this dispute. The leaders of Ajak and Monyjooc were concerned not only with accessing the potential resources of the state, they wanted recognition as legitimate communities. They wanted literally to be seen as the President's convoy passed through Mayar.

It is striking that the community leaders were explicitly drawing on symbols of state authority to make claims on Mayar. Both communities made appeals to authority through the mediums of literacy and writing, which have been long associated in South Sudan with government authority. Through education, court proceedings or ballot papers, paper has long been a principal means to 'tap the powers of the government' (Hutchinson 1996:283-284). In 2011 the Monyjooc community had erected a sign with the name Mayar-Monyjooc written on it, which had been prominently displayed even to the non-literate Ajak elders who were unable to read the words. The Ajak community in turn contested the Monyjooc community meeting by writing a letter. The erection and removal of a flag - a clear symbol of government authority - also indicates how employing the material culture of government was an important means through which claims were being articulated. Both sides wanted to achieve recognition, in the eyes of the state as 'communities'. Through the exchange of written words and papers both sides appealed to the implicit threat of state violence to make their claims (Tuttle 2013:232). 
The fact that Manar is not a grazing border, therefore not a 'traditional' site of conflict, highlights that there is a very new set of concerns that are being worked out at these administrative borders. These are not only concerns about accessing grazing land and other natural resources. The 'paper-based' claims, using symbolic tools of the government that were being made at Manar underscore concerns to be included in the state and government structures and to be recognized as a defined community of citizens. The reality of the socio-territorial nature of wut, what colonial administrators lamented as the 'hopeless mixture' of relationships will always elide simple state inscription. Yet the last hundred years have been a story of the increasing political importance of territoriality, as a result community leaders articulate support around territorial notions of identity.

\section{CONCLUSION}

In Gogrial, the state did not simply bring boundaries into an unmarked space: it has tried, in Ingold's formulation, to join the dots (Ingold 2007:74-75). This has been a complex process. In some respects, the Dinka galactic border does have some similarities with 'state-like' borders, as the model does emphasize the edges as well as the centre of territory (c.f. Tambiah 1977). But in other ways it is very different because these are not enclosed territories, nor they are not defined in a Weberian sense, yet these constellations of points are borders and contain potent historical claims of ownership.

The state has long attempted to make administrative borders consonant with the borders of Dinka wust. As these borders are mapped onto the landscape they may appear to be parallel, but this apparent commensurability masks their distinctiveness. These different logics have created a slippage in authority and meaning over what the border is. This ambiguity has led to competing claims of authority at local administrative boundaries: as Dinka models of sociality, territoriality and the border, which continue to form the basis of local historical claims, sit uneasily alongside the state's administrative geography. The state has tried to capture Dinka segmentary political structures for its administrative geography. But the process has also been driven from the other direction, as people have increasingly come to invest in that political geography and imbue it with their own meanings. This can result in heightened tensions and sometimes violence at administrative borders as people try, successfully and unsuccessfully, to accommodate distinct moral paradigms of mapping claims of entitlement onto the landscape. 
Recognition that there are indigenous ideas about borders in pastoralist societies provides a useful corrective to latently orientalist imaginations of pastoralists as anarchic wanderers. The compartmentalization that exists in studies of pastoralism between 'pastoralist landscapes' and 'state landscapes' as diametrically opposed and ontologically distinct may not be accurate or useful (Watson 2010). There are different logics of what a border is that are in operation and these have shaped each other, both today and in the past. Further, pastoralists tend to live in places where the post-colonial state is, after all, unable to enforce its bureaucratic and administrative ideals (Moritz 2005). Nowhere has this been clearer than in the rural peripheries of the nascent South Sudanese state. The effects of this situation are various, as well as the political instrumentalisation of local conflicts (Thomas 2015; Greiner 2013); recent disputes like the one at Mayar demonstrate how rural people in South Sudan, at certain points in time, have also been selectively engaging with, and transforming, the power of the government.

\footnotetext{
${ }^{1}$ Sudan Archive Durham (SAD) Sudan Government Staff lists.

2 SAD Collins 930/2 Extracts from Minutes of Dinka DC meeting held at Tonj 2126.01.1938.

3 SAD Collins 930/2 Extracts from Minutes of Dinka DC meeting held at Tonj 2126.01.1938.

${ }^{4}$ Pitt Rivers Museum Manuscript Collection (PRM) Godfrey Lienhardt Papers Box 1, Item 8 'Minutes of the Jur River District Chiefs Meeting, Gogrial 1-4 December 1946.

5 Amet Kuol was 'known' to the administration and he had come to Wau to talk with officials in 1904, see SAD 275/9/40 Wingate 'Sudan Notes' Dec 1904. The Comboni fathers had also negotiated with him to build the mission at Kuajok, see La Nigrizia March 1924, 'Prima Stazione tra I Denka'. Kuanyin Agoth's grandson described how he was willing to talk to the government when they came to Gogrial. Interview with Mabior Wek Kuanyin, Gogrial Town, Gogrial West 2.11.2011. A son of Giir Thiik told me a story in which Giir had come to his chiefly position after showing bravery in the face of the government, while everyone else was afraid. Interview with Akol Giir Thiik, Kuajok, Gogrial West 22.10.2011.

${ }^{6}$ Note on Owen 57.B.23.4.1927 in Collins SAD 946/3.

7 There were disputes when this boundary was drawn. (Makec 1988:184).

8 PRM Godfrey Lienhardt Papers Box 2, Item 1 'Fieldwork Notebook on the Dinka', beginning 1947. Entry on 26.01.1948.
} 
${ }_{9}^{9}$ PRM Godfrey Lienhardt Papers Box 2, Item 1 'Fieldwork Notebook on the Dinka' beginning 1947. Entry on 11.01.1948, diagrams at the end of entry on 1718.01.1948.

10 These numbers are based on information complied during my fieldwork in Gogrial 2011-2012. It was difficult to get 'official' names and numbers of administrative units. This information is based on a list dictated to me in the Ministry of Local Government in Kuajok on 21.07.2012. crosschecked with key informants and on my behalf by Samuel Buol Malith. Names of bomas (and in some cases the numbers per payam) varied.

11 Maluil Maluil Agany, Gogrial Town, Gogrial West 8.3.2012.

12 Recorded near Luonyaker, Gogrial East 11.06.2012.

13 Recorded in Mawut, Gogrial East 14.06.2012.

14 Since field research was carried out several other boundary disputes, between Warrap state and Western Bahr el Ghazal have been reported. At Nyinakok and more recently at Tharkueng. See (Sudan Tribune 2014; Gurtong Media 2015) 15 A copy of this letter was included in the reconciliation meeting report.

16 Details based on conversations in Kuajok Jan 2012 and 'Peace and Reconciliation Report on Monyjooc and Ajak Communities conflict' prepared by Pingkurot Group presented to the acting governor of Warrap State 11 Jan 2012. 17 Ibid. p.5.

18 Ibid. p.5-6.

19 Titherington, G.W. (1927) 'The Raik Dinka of the Bahr El Ghazal Province,' Sudan Notes and Records 10: 205, 'Map of the Raik Dinka Country'.

20 PRM Godfrey Lienhardt Papers Box 4, Item 1 'A Fieldwork Notebook', date unknown.

21 PRM Godfrey Lienhardt Papers Box 5, Item 5 'Notebook 2, 1948'. Entry on 05.03.1948. Lienhardt specifically asked Giir Thiik to tell him about the wust of Apuk 'before the government came'.

22 Interview with Bol Cuor, Angui, Gogrial West 28.10.11.

${ }^{23}$ At the end of British colonialism, chiefs in Gogrial were expected to maintain minor roads 'free of charge' SAD 769/1/33 P.P.

${ }^{24}$ National Records Office (NRO) Khartoum EP 2/35/128 DCs Tonj and Lakes to Governor, 13.04.1939. Luac-Agar (Pakkam) fight 1938.

${ }^{25}$ NRO Khartoum EP 2/35/128 DC Lakes to DC Tonj, 28.03.1940 and DC Tonj to DC Lakes 13.03.1939.

${ }^{26}$ NRO Khartoum EP 2/35/128 DC Lakes to DC Tonj, 28.03.1940.

${ }^{27}$ NRO Khartoum EP 2/35/128 DC Lakes to DC Tonj, 27.02.1940.

${ }^{28}$ NRO Khartoum EP 2/35/128 DC Lakes to DC Tonj, 27.02.1940.

\section{ACKNOWLEDGEMENTS}

The research for this article was financially supported by an AHRC doctoral award, the Martin Lynne Travel Award from the Royal Historical Society and a small grant from the British Institute in Eastern Africa. Cherry Leonardi, Ben Campbell and Steven Pierce gave very useful feedback on earlier drafts. Elizabeth Watson invited me to present a version of this article at the conference, Reconfiguring Landscapes and Bio-Cultural Frontiers in Eastern Africa at the British Institute in Eastern Africa in 2014. Two anonymous reviewers provided 
very useful comments. Most of all I would like to thank all who helped me in South Sudan, in particular Adut Madut Akec and Deng Mariak Deng for their kindness and hospitality.

\section{BIBLIOGRAPHY}

Abbink, J. (1997) 'The shrinking cultural and political space of East African pastoral societies', Nordic Journal of African Studies 6 (1): 1-17.

Anderson, D. (2002) Eroding the Commons: the politics of ecology in Baringo, Kenya 1890-1968. Oxford: James Currey.

Beaton, A.C. (1949) Equatoria Province Handbook. Khartoum: Sudan Government Publications.

Beinart, W, K. Brown, and D. Gilfoyle (2009) 'Experts and expertise in colonial Africa reconsidered: science and the interpenetration of knowledge', African Affairs 108 (432): 413-433.

Bender, B. (1999) 'Subverting the western gaze: mapping alternative worlds' in P. J Ucko and R. Layton (eds), The Archaeology and Anthropology of Landscape: shaping your landscape. New York: Routledge.

Brockington, D. (2002) Fortress Conservation: The preservation of the Mkomazi Game Reserve, Tanzania. Bloomington, IN: Indiana University Press.

Catley, A, J. Lind, and I. Scoones, eds. (2013) Pastoralism and Development in Africa: dynamic change at the margins. London: Routledge and Earthscan.

Collins, R. O. (1983) Shadows in the Grass: Britain in the Southern Sudan, 19181956. New Haven: Yale University Press.

Das, V. and D. Poole (2004) Anthropology in the Margins of The State. Sante Fe: School of American Research Press.

Deng, F. M. (1978) Africans of Two Worlds: The Dinka in the Afro-Arab Sudan. New Haven: Yale University Press.

Evans-Pritchard, E.E. (1969) The Nuer: A description of the modes of livelihoods and political institutions of a Nilotic people. Oxford: Oxford University Press

Fratkin, E. (1997) 'Pastoralism: governance and development issues,' Annual Review of Anthropology 26: 235-261.

Gamaledin, M. (1993) The decline of Afar pastoralism in J. Markakis (ed). Conflict and the Decline of Pastoralism in the Horn of Africa. London: Macmillan.

GOSS (2009a) The Local Government Act. Juba: Government of Southern Sudan. 
GOSS (2009b) Southern Sudan: Overview of States and Counties. Juba: Southern Sudan Centre for Statistics and Evaluation.

Greiner, C. (2013) 'Guns, Land and Votes: Cattle Rustling and the Politics of Boundary (re)making in Northern Kenya', African Affairs 112 (447): 1-22.

Gurtong Media (2015) 'Border dispute clash between Warrap-WBGS leaves one person dead', 30 January

<http://www.gurtong.net/ECM/Editorial/tabid/124/ctl/ArticleView/mid/519/ articleId/16111/Border-Dispute-Clash-Between-Warrap-WBGS-Leaves-OnePerson-Dead.aspx>, accessed February 12, 2015.

Harragin, S, and C. C. Chol (1998) The Southern Sudan Vulnerability Study. Nairobi: Save the Children (UK).

Herbst, J. (2000) States and Power in Africa: comparative lessons in authority and control. Princeton: Princeton University Press.

Howell, P, M. Lock, and S. Cobb (1988) The Jonglei Canal: impact and opportunity. Cambridge: Cambridge University Press.

Hughes, L. (2006) Moving the Maasai: a colonial misadventure. London: Palgrave Macmillan.

Hutchinson, S. (1996) Nuer Dilemmas: coping with money, war and the state. Berkeley: University of California Press.

Ingold, T. (2007) Lines: a brief history. London: Routledge.

Johnson, D. H. (1982) 'Tribal boundaries and border wars: Nuer-Dinka relations in the Sobat and Zaraf Valleys, c.1860-1976', The Journal of African History 23 (4): 183-203.

Johnson, D. H. (1998) 'The Sudan People's Liberation Army and the problem of factionalism', in C. Clapham (ed), African Guerillas. Oxford: James Currey.

Johnson, D. H. (2011) The Root Causes of Sudan's Civil Wars: peace or truce. Suffolk: James Currey.

Leonardi, C. (2013) Dealing With Government in South Sudan: histories of chiefship, community and state. Suffolk: James Currey.

Lienhardt, G. (1958) 'The Western Dinka' in J. Middleton and D.Tait (eds) Tribes Without Rulers: Studies in African Segmentary Systems. London: Routledge.

Lienhardt, G. (1961) Divinity and Experience: The religion of the Dinka. Oxford: Clarendon Press. 
Lienhardt, G. (1982) 'The Sudan: aspects of the south government among some of the Nilotic peoples, 1947-1952,' Bulletin (British Society of Middle Eastern Studies) 9(1): 22-34.

Luedke, A. (2013) 'Increasing Conflict Over Internal Boundaries in South Sudan' in A Periodic Newsletter from the South Sudan Law Society 1: 6.

Makec, J. W. (1988) The Customary Law of the Dinka People of Sudan: In Comparison with Aspects of Western and Islamic Laws. London: Afroworld Publishing Co.

Mazarire, G. C. (2013) 'The Gadzingo: towards a Karanga expansion matrix in 18th and 19th century southern Zimbabwe' in Critical African Studies 5(1): 4-16.

Middleton, J. and D. Tait, eds. (1970) Tribes Without Rulers: studies in African segmentary systems. London: Routledge.

Moritz, M. (2005) 'FulBe pastoralists and the neo-patrimonial state in the Chad Basin,' in Geography Research Journal 25: 83-104.

Norris, M.W (1983) 'Local government and decentralisation in the Sudan,' in Public Administration and Development 3: 209-222.

Ranger, T. (1993) 'The invention of tradition revisited: the case of Africa,' in T. Ranger and O. Vaughan, (eds) Legitimacy and the State in Twentieth Century Africa. London: Macmillan.

Reno, W. (2011) Warfare in Independent Africa. Cambridge: Cambridge University Press.

Reyna, S. (1990) Wars Without End: The political economy of a precolonial African state. Hanover and London: University Press of New England.

Rolandsen, Ø. (2005) Guerrilla Government: political changes in the southern Sudan during the 1990s. Leiden: Nordiska Afrikainstitutet.

Rolandsen, Ø. (2009) Land, Security and Peace Building in Southern Sudan. Oslo: International Peace Research Institute.

Ryle, J. and S. Errington (1982) The Dinka: warriors of the White Nile. Amsterdam: Time Life Books.

Santschi, M. (2008) 'Counting "New Sudan," in African Affairs 107(429): 631640. 
Santschi, M. (2013) 'Encountering and "Capturing” Hakuma: negotiating statehood and authority in Northern Bahr-El-Ghazal State, South Sudan.' PhD dissertation, University of Bern.

Schlee, G. (2010) Territorialising Ethnicity: The political ecology of pastoralism in Northern Kenya and Southern Ethiopia. Halle: Max-Planck Institute.

Schlee, G. and A. A. Shongolo (2011) Pastoralism and Politics in Northern Kenyan and Southern Ethiopia. Suffolk: James Currey.

Schomerus, M. and T. Allen (2010) Southern Sudan at Odds With Itself: dynamics of conflict and predicaments of peace. London: LSE.

Seligman, C. G, and B. Z. Seligman (1932) Pagan Tribes of the Nilotic Sudan. Routledge \& Sons.

Sharma, A. and A Gupta (eds) (2006) The Anthropology of the State: a reader. Oxford: Blackwell.

Spear, T. (2003) 'Neo-traditionalism and limits of invention in British colonial Africa,' The Journal of African History 44(1): 3-27.

Sudan Tribune (2012) 'South Sudan: 9 People Killed in Bahr El Ghazal', January 1. http://www.sudantribune.com/spip.php?article41155, accessed March 1, 2014.

Sudan Tribune (2013) 'New Grazing Rights Deal Between Warrap and Lakes State', March 21, accessed March 5, 2014.

Sudan Tribune (2014) 'Fact Finding Committees to determine location of disputed Nyinakok area', September 23

http://www.sudantribune.com/spip.php?article51782, accessed February 12, 2015.

Tambiah, S. (1977) 'The Galactic Polity: the structure of traditional kingdoms in Southeast Asia,' Annals of the New York Academy of Sciences 293: 69-97.

Thomas, E. (2010) The Kafia Kingi Enclave: people, politics and history in the north-south boundary zone of western Sudan. London: Rift Valley Institute.

Thomas, E. (2015) South Sudan: A Slow Liberation. London: Zed Books.

Titherington, G.W. (1927) 'The Raik Dinka of the Bahr El Ghazal Province,' Sudan Notes and Records 10: 159-209.

Todisco, C. (2015) Real but Fragile: The Greater Pibor Administrative Area. Geneva: The Small Arms Survey.

Turner, M. (1999) 'The role of social networks, indefinite boundaries and 
political bargaining in maintaining the ecological and economic resilience of the transhumance systems of Sudano-Sahelian West Africa' in M. Niamir-Fuller (ed) Managing Mobility in African Rangelands: The legitimization of transhumance. London: Intermediate Technology Productions.

Tuttle, B. (2013) Life Is Prickly: narrating history, belonging, and common place in Bor, South Sudan. PhD dissertation, Temple University.

Umbadda, S. (2014) Agricultural investment through land grabbing in Sudan in J. Gertel, R. Rottenburg, and S. Calkins (eds) Disrupting Territories: land, commodification and conflict in Sudan. Suffolk: James Currey.

UNOCHA (2008) Payams of Southern Sudan. Juba: United Nations Office for the Coordination of Humanitarian Affairs.

Waller, R. (2004) "Clean" and "Dirty": cattle disease and control policy in colonial Kenya,' The Journal of African History 45(1): 45-80.

Watson, E. (2010) 'A Hardening of Lines: landscape, religion and identity in northern Kenya,' The Journal of Eastern African Studies 4(2):201-220.

Willis, J. (2003) 'Violence, authority, and the state in the Nuba Mountains of condominium Sudan,' The Historical Journal 46(01): 89-114. 